\title{
The Hygienic Quality of Raw Romanian Goat Milk Depending on the Milking Season
}

\author{
Zorica VOŞGAN*, Lucia MIHALESCU, Stela JELEA, Anca DUMUȚA, Flavia POP \\ Department of Biology, Technical University of Cluj-Napoca, North University Center of Baia Mare, no.76, Victoriei Street, Baia \\ Mare, Romania; \\ "corresponding author, e-mail: zori_v13@yahoo.com
}

Bulletin USAMV series Agriculture 75(1)/2018

Print ISSN 1843-5246; Electronic ISSN 1843-5386

DOI 10.15835/buasvmcn-agr: 001017

\begin{abstract}
The milk samples were yielded by manual milking from a goat farm that was maintained in extensive system, at monthly intervals during the production period (spring, summer, autumn). Goat milk from a traditional stall in the Maramures County, depending on the lactation period and the season has been analyzed in this study. The milk samples were collected aseptically and transported in laboratory for microbiological analysis. During springtime, when milking is done three times a day, and the amount of milk is higher, the total number of germs is $77.8 \times 10^{3}$ $\mathrm{CFU} / \mathrm{ml}$. A smaller number compared to the number of microorganisms recorded in the summer $\left(97.3 \times 10^{3} \mathrm{CFU} /\right.$ $\mathrm{ml}$ ) when milking is done twice a day and there are higher temperatures. During autumn, in the conditions of low milk production, at the end of the lactation period and when the samples are harvested only once a day, the number of microorganisms was $81.5 \times 10^{3} \mathrm{CFU} / \mathrm{ml}$. Somatic cells from milk indicating an excess of the normal values especially towards the end of the lactation period. Particular attention should be paid to hygiene conditions when handling milk, to improve its quality. Thus, goat milk has a higher bacterial load (SPC) during summer, and SCC exceeds the recommended limits, especially in the autumn.
\end{abstract}

Keywords: microorganisms, milk, traditional

\section{Introduction}

In our country, the perspective of the development of the goat sector is growing, but it still suffers from the lack of an organized program of raising and improvement. Goats are spread mainly in the hilly, mountainous areas around some urban localities, in small households with a number of two or three heads, as well as in groups of 40-60 heads, and even in specialized farms (Tafta, 2002). According to the National Institute of Statistics, in Romania the total number of goats was 1.240 .858 heads, of which in the Maramures County, the number of goats is 17.744 heads. Goats exploit the crop obtained from the mountain pastures and natural hills, as their agility makes them to easier access the most rugged lands to search for and select their food (leaves, buds, branches and grass), to which other species of livestock would have not access. Due to these facts, goat is a rustic and easy-to-raise livestock, and small hill farmers successfully raise these animals especially for their superior lactogeny and quick breeding.

The amount of milk produced by goats exceeds 10 to 20 times their own body weight, depending on their degree of improvement and the applied nutrition level, compared to cows, for which it is only 6 to 8 times higher (Tafta, 2002).

The activities carried out in a herd of goats raised and maintained in an extensive system and milking practices that may influence milk hygienicsanitary conditions. Milk and milk products are a rich and convenient source of nutrients for people, but appropriate safety measures must be ensured in order to protect the consumers' health. All foods have the potential to cause food borne illness, and milk and milk products are no exception. Pathogens found in milk may increase the risk of disease; in addition, the milking procedure, subsequent milk collection and storage increase 
the risks. The implementation of adequate hygiene control of milk and dairy products is essential.

In Maramures County, traditional farming practices are still preserved by the livestock breeders, who are trying to get salubrious dairy products appreciated by the consumers. This is not easy, because the risk of contamination or deterioration at the place of production (farms) exists either through sick animals or infectious diseases, or through external sources. Contamination of goat milk usually is in the form of hair, insect part, particles of dust, feed or manure, or bacteria associated with these contaminants plus unclean utensils (Loewenstein and Speck, 1992). The microbiological content of raw milk affects quality, shelf life and safety of the processed milk and other dairy products (Gunasekera et al., 2000), which would affect the marketing of products on the market. The implementation of hygienic practices at the time of milking is therefore one of the first and most important step in clean milk production (Sinha, 2000; Abdalia and Ibtisam Zubeir, 2007). Thus, it is necessary to study the current situation of goat farms with respect to the hygiene-sanitary quality of the milk under different forms of management, and to examine the degree of appropriateness of and compliance with legal requirements (DelgadoPertiñez et al. 2003).

The research carried out was aimed at the hygienic quality of goat raw milk, obtained by manual milking, in order to improve the practices performed within the herd. A periodic examination of the sanitary-sanitary quality of milk, of the total number aerobic bacteria and somatic cell present in milk at the time of the take-over from the farm, is necessary.

\section{Materials and methods}

The present study was conducted in a goat farm in the Maramures County; these goats have been raised and maintained extensively during the 9-month lactation period (March-November). Milk samples were periodically harvested by seasons: spring, summer and autumn by manual milking.

Additional measures have been taken on manual milking by washing the hands of the milker, clean clothes, cleaning the milking equipment, the existence of a specific milking site; harvesting was done in the morning under aseptic conditions in labeled sterilized bottles and kept under refrigerated conditions (kept in ice box at $0-4^{\circ} \mathrm{C}$ ). Laboratory analysis was conducted always within $24 \mathrm{~h}$ from sampling.

Microbiological analysis were performed each season: bacterial counts carried out with Standard Plate Count (SPC) and somatic cell count (SCC) in milk.

The STAS ISO 4833-2003 revised by ISO 4833-1:2013 standard was used as an operational method. The milk sample was diluted in sterile physiological saline solution and aseptically transferred into Petri dishes, over which the PCA (plate count agar) culture environment was added.

The plates were incubated at $30^{\circ} \mathrm{C}$ for 48 hours, after which the colonies were counted. The arithmetic mean and geometric mean of the obtained values were calculated every season. The results were expressed as $\log \mathrm{CFU} / \mathrm{ml}$.

The assessment of somatic cell count was performed by the rapid fluo-opto-electronic method ISO 13366-2 (2006). The rapid method's principle is a combination of flow-citometry and laser reading (Rotar et al., 2010). SOMACOUNT requires the use of a chemical preparation, ethidium bromide (glucount tablets), to stain DNA for white blood cell count. The microscopic method could be used to calibrate the electronic and mechanized procedure, by displaying the tested milk on the slide.

\section{Results and discussions}

The farming procedures and practices in livestock farms can greatly influence the quality of milk production, and through microbiological examinations, the degree of the hygiene of raw milk, which is subsequently used as a raw material for bio-products, could be assessed. The hygienic state of milk is extremely important, so microbiological risks must be traced back to the source. The assessment of the hygiene of manually milked raw milk of the goat farm, from which traditional natural cheese is subsequently prepared, was performed by bacteriological and somatic cells examination, according to the season. Even if the same hygienic conditions of the milkmen were observed, the degree of microorganism load differs, depending on the goat milk sample collection season.

During springtime, at the beginning of the lactation period, when the milk production is higher, the mean arithmetic of the total number of 


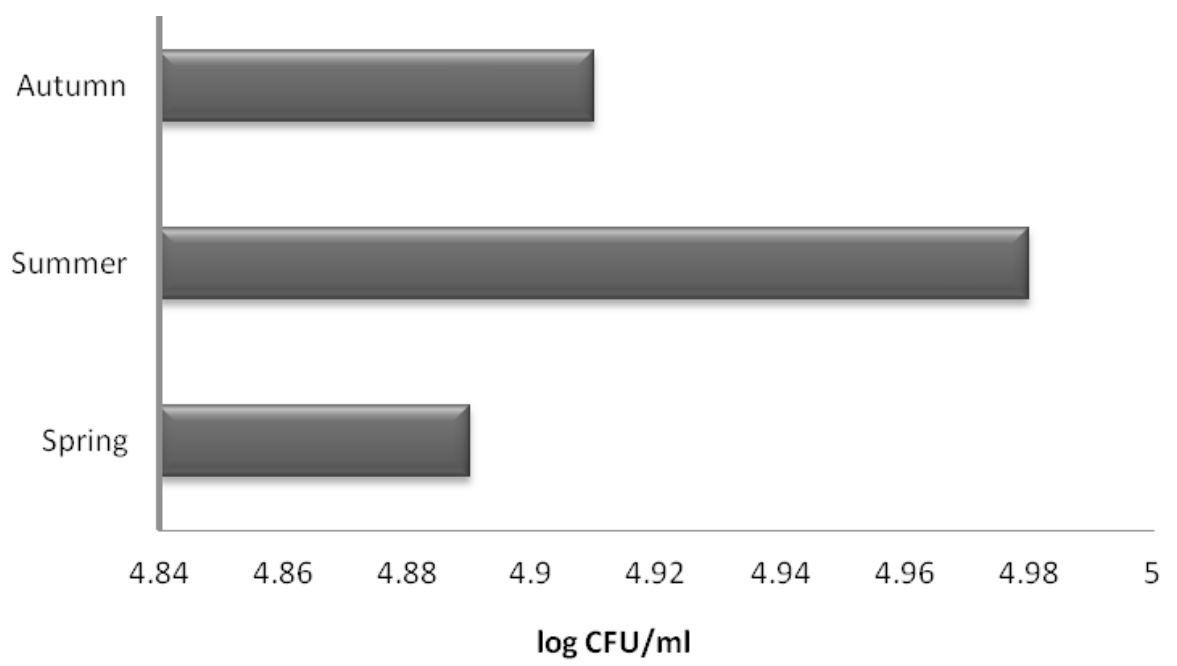

Figure 1. Logarithmic values of total number of germs/ml goat milk depending on the season

Table 1. Average values of the number of somatic cells in goat milk by seasons

\begin{tabular}{cccc}
\hline Season & Spring & Summer & Autumn \\
\hline$S C C / m l$ & 509.000 & 516.000 & 1.872 .000 \\
\hline
\end{tabular}

germs in the sampling interval was calculated at $77.800 \mathrm{CFU} / \mathrm{ml}$ goat milk, and the geometric mean of $77.799 \mathrm{CFU} / \mathrm{ml}$, ascertained over a 3-month period. In the summer, during the three-month sampling interval, the calculated mean value was 97.300 $\mathrm{CFU} / \mathrm{ml}$, due to the higher temperatures which influence the hygiene degree. The geometric mean is $96.470 \mathrm{CFU} / \mathrm{ml}$, with a moderate monthly fluctuation over the 3 month period. In the autumn, by the end of the lactation period, the contamination degree was $81.500 \mathrm{CFU} / \mathrm{ml}$ milk, this representing the mean value calculated for the sampling interval and the geometric mean of 81.447 CFU/ml is constant.

Thus, there is a variation in the total number of germs, depending on the yielding season and the lactation period, as it is also shown in the Figure 1 , subsequent to the logarithm of the obtained average values.

As of 1 January 2014, in the case of raw milk, the requirements of the EU legislation regarding the total number of germs and the number of somatic cells must be observed according to the regulations Regulation (EC) No 853/2004 of the European Parliament and of the Council of 29 April 2004 laying down specific hygiene rules for food of animal origin (Official Journal of the European Union L 139 of 30 April 2004). In raw milk from species other than cows, food business operators must take measures to ensure that the total number of germs at $30^{\circ} \mathrm{C} / \mathrm{ml} \leq 500000$. The obtained results confirm that in the three seasons the maximum admissible values of raw goat milk are not exceeded.

As for the number of somatic cells (which provide information on the health of the udder), according to the same regulation, it should be below 400.000 cells $/ \mathrm{ml}$.

An overdose of the somatic cell count was found in the analyzed milk samples, which was obvious during the last three months of lactation (Table 1). Olechnowics and Jaskowics (2004) argue that the somatic cell number of goat milk is generally higher than the number of somatic cells in cow and sheep milk.

This indicates an inflammatory reaction of the udder, especially at the end of lactation period, when milking is done once a day and the amount of milk is lower. The number of somatic cells in raw goat milk is higher towards the end of the lactation period, due to the physiological increase of milk cells towards the end of lactation (RaynalLjutovac et al., 2007; Rotar et al., 2010). Available data indicate that the SCC is highest during autumn and lowest during spring (Dankow et al., 2003), which is also the result of the research carried out. Increase of SCC in milk is associated with increased proteolyti (i.e., plasmin) and lipolytic (i.e., lipoprotein lipase) activities (Zeng et al. 2007). The studies conducted by Ma et al., 2000 
show that a high SCC in raw milk accelerated the development of sensory defects such as rancidity and bitterness.

\section{Conclusion}

Raw goat milk, collected from a traditional farm and yielded by manual milking according to local practices, has an acceptable bacterial quality, but did not meet the recommended SCC quality level.

Establishing appropriate sanitary and hygienic conditions would improve the bacteriological quality (SPC) of milk and allow SCC to fall below the recommended limits. When handling milk, particular attention to hygienic conditions can improve its quality; although this result can also be influenced by the environmental factors, because, during summer, the level of microorganism load is higher. The presence of SCC was more obvious at the end of the lactation period, and it could be caused by some factors such as breed, existence of subclinical mastitis, etc.

The results suggest that it is worthwhile to encourage the small farmers, because improving the quality of life will be possible as long as we do not disrupt nature in a spectacular way, and we will try to preserve the traditional values.

\section{References}

1. Abdalla MEM and Ibtisam Zubeir EMEI $\backslash(2007)$. Effects of Different Management Practices on Milk Hygiene of Goat Farms in Khartoum State, Sudan. International Journal of Dairy Science, 2: 23-32.

2. Dankow R, Cais-Sokolinska D, Pikul J, Wojtowski J (2003). Cytological quality of goat's milk. MedycynaWeterynaryjna, 59(1):77-80.
3. Delgado-Pertiñez M, Alcalde MJ, Guzmán-Guerrero JL, Castel JM, Mena Y, Caravaca F (2003). Effect of hygienesanitary management on goat milk quality in semi extensive systems in Spain. Small Ruminant Research, 47: 51-61.

4. Loewenstein M and Speck SJ (1992). Producing quality goat milk. Extension. Goat Hand Book. No E-4, United State.

5. Ma Y, Ryan C, Barbano DM, Galton DM, Rudan M, Boor K (2000). Effects of somatic cell count on quality and shelflife of pasteurized fluid milk. J. Dairy Sci., 83:264-274.

6. Olechnowics J and Jaskowicz JM (2004). Somatic cells in goat milk. Medycyna Weterynaryjna, 60 (12):1263-1266.

7. Raynal-Ljutovac K, Pirisi A, De Cremoux R, Gonzalo C (2007). Somatic cells of goat and sheep milk: analytical, sanitary, productive and tehnological aspects. Small Ruminant Research, 68: 126-144.

8. Rotar AM, Apostu S, Lazar C, Semeniuc A (2010). A study regarding the relationship between somatic cell count and bacteriological exam at goat milk. Journal of Agroalimentary Processes and Technologies, 16(2):150154.

9. Tafta V (2002). Producția și reproducția caprinelor, Ed. Ceres, 98-119, Bucureşti.

10. Zeng SS, Chen SS, Bah B, Tesfai K (2007). Effect of Extended Storage on Microbiological Quality, Somatic Cell Count, and Composition of Raw Goat Milk on a Farm. Journal of Food Protection, 70(5):1281-1285.

11.*** ISO 4833:2003 Microbiology of food and animal feeding stuffs -- Horizontal method for the enumeration of microorganisms -- Colony-count technique at 30 degrees C.

12. *** ISO 4833-1:2013 Microbiology of the food chain -Horizontal method for the enumeration of microorganisms -- Part 1: Colony count at 30 degrees $\mathrm{C}$ by the pour plate technique.

13. *** ISO 13366-2 (2006): Part 2: Guidance on the operation of fluoro-opto-electronic counters. In: Milk Enumeration of Somatic Cells. International Organization for Standardisation, Geneva, Switzerland. 